\title{
発語失行症患者の単語アクセント生成における 調音器官と発声器官の協調運動の異常
}

\author{
正木 信夫 辰巳 格 笹沼 澄子
}

\begin{abstract}
要 約：発語失行症患者の発語における, 調音器官と発声器官の協調運動について検討した。 純粋な症例 1 例と健常対照群の，[ai] および $[\mathrm{amV}](\mathrm{V}=\mathrm{a}, \mathrm{e}, \mathrm{i})$ で始まる平板型・尾高型 アクセントの単語発話を発話試料とした。[ai]で始まる単語については，アクセント指令と第 2 拍 [i] の調音指令を, それぞれ基本周波数とフォルマント周波数から, 日本語の単語アクセ ント生成および調音運動生成の機能的モデルに基づいて推定した，発語失行症患者では，発話 速度が遅い場合にアクセント指令の調音指令に対する遅れが健常者に比べ著しく大きかった。 また， $[\mathrm{amV}]$ で始まる単語の発話では，アクセント指令の，[m] の唇閉鎖時点に対する遅れ が健常者に比べて大きかった。従来, 発語失行症患者の発話における調音器官同士の協調運動 に異常が起こることは報告されてきた。しかし, 本研究の結果では協調運動の異常は調音器官 同士ばかりでなく, 調音器官と発声器官の間にも起こりうることが示された。
\end{abstract}

索引用語: 発語失行症, アクセント, 調音, 韻律, 基本周波数

Abnormality in Coordination between Articulators and Vocal Organ in the Realization of Japanese Word Accent by Patient with Apraxia of Speech

\section{Shinobu Masaki, Itaru F. Tatsumi and Sumiko Sasanuma}

\begin{abstract}
The possibility of disturbance of temporal coordination between articulators and vocal organ was examined in apraxic speech. Speech samples consisted of Japanese words beginning with [ai] or [amV] $(\mathrm{V}=\mathrm{a}$, e, or i) and having a low-high type accent pattern, uttered by a patient with pure apraxia of speech and normal controls. For words beginning with [ai], the accent command and articulatory command for the second vowel [i] were estimated from fundamental and formant frequencies, respectively, based on the functional model for realization of Japanese word accent and articulation. The results showed that delay of onset of the accent command relative to that of the articulatory command was markedly larger in apraxic speech than that in normal speech at a slow speaking rate. For words beginning with [amV], the delay of onset of the accent command relative to lip closure for $[\mathrm{m}]$ was larger in apraxic speech than that in normal speech.
\end{abstract}

東京都老人総合研究所言語聴賞研究室： $=173$ 東京都板橋区栄町 35=2

Section of Language and Communication Research, Tokyo Metropolitan Institute of Gerontology : 35-2 Sakae-cho, Itabashi -ku, Tokyo 173, JAPAN

原稿受理: 平成元年 5 月 31 日 
vol. 31 No. $2,1990.4$

Several previous studies have reported on abnormalities of temporal coordination among different articulators in apraxic speech. However, our results in the present study suggest that abnormalities of temporal coordination exist between articulators and vocal organ as well.

Key words : apraxia of speech, accent, articulation, prosody, fundamental frequency

\section{I 。はじめに}

発語失行症は脳損傷に起因する発話障害である。純 路では離散的な言語符号の処理に障害がなく，また， その発話障害は調音器官および発声器官の麻痺による ぇのではないとされている゙!.

発語失行症患者の発話異常は調音と韻律の両面にわ そって出現する，調音に関しては，聴覚印象やサウン トスペクトログラフに基づく研究がなされている2 11 か，最近になりファイバースコープやX線マイクロビ 一ムを用いた調音運動の直接観測により, 発語失行症 の調音異常が, 舌・唇・口蓋帆等の複数の調音器官の 坻調運動の破綻により生ずることが明らかにされ $t^{12-14)}$.

一方，韻律に関しては，音響分析に基づき，(1)発話 速度が遅い, (2)各拍の持続時間は健常者のそれよりも 長い, (3)音節の間にポーズが置かれることが多い, 等

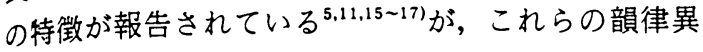
常を調音の困難さに伴う「補償現象」とみなす立場も ある ${ }^{1}$. しかし, 現在のところ発語失行症における韻律 異常は, 詳細に調べられてはいない。特に, 基本周波 数が重要な役割を果たす日本語の単語アクセントにつ いては, 聴覚印象に基づき単語アクセントを区別して 生成する能力は保たれているとする報告5)があるにす ぎい，単語アクセントに関する定量的な検討が遅れ た理由の 1 つは, 上記の報告が示すように, 聴覚印象 だけからは異常が検出されないため, 分析の対象とさ れる機会が少なかったことにあると考えられる。さら に, 以下に述べるように音声分析と結果の解釈が難し いことも研究の遅れの一因をなしていると推察され ろ.

一般に，単語の発話ないし聴取において，単語は相 互に独立で離散的な拍をつなぎ合わせたものであり, 拍と拍との境界はきわめて明白なものと意識される. また, 単語アクセントに対応した声の高低パタンも, 単語の拍ごとに離散的に変化し, 声の高低の境界は拍 の境界と一致したものと意識される。しかし調音器官 の運動と発声器官の運動は, それぞれに固有の物理 的・生理的制約のため平滑化され，いわゆる調音結合
が生じる。したがって，実際に発話された音声では， 調音運動の結果として現れるフォルマントの軌跡と, 発声器官の運動の結果として現れる基本周波数パタン は，いずれも連続的な変化を示すため，実際に観測さ れたこれらの物理量から拍の境界と声の高低の境界を 知り，両者の関係を把握することは容易ではない.

藤崎らは，この困難を克服する方法として，連続的 に変化するフォルマント周波数および基本周波数の実 測值から，拍と声の高低の境界を推定するモデルを考 案した ${ }^{18)}$. 彼らは, 健常者に母音連続からなる 2 拍単語 を発話させ，音響分析によりフォルマント周波数と基 本周波数を抽出した.フォルマントの軌跡から各拍の 境界にあたる調音指令の始点を，また，基本周波数パ タンから声の高低の境界にあたるアクセント指令の始 点の推定を行った。 その結果, 調音指令はアクセント 指令に数十ミリ秒先行して発せられており, 調音器官 と発声器官が協調運動していることが明らかとなっ た。

本研究では, 藤崎らの手法に基づき，ほぼ純粋と思 われる発語失行症患者 1 名の単語発話の分析を行い, 発語失行症患者では調音器官と発声器官の協調運動が 健常者と同様に保たれているかどうかを検討した，実 験 1 では, 語頭が 2 連母音からなる平板型・尾高型の アクセント ${ }^{199}$ を持つ単語を試料とし, 発語失行症患者 における調音指令とアクセント指令の時間関係を調べ

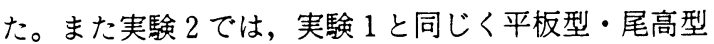
のアクセントを持つが, 語頭の第 2 拍目に子音 $[\mathrm{m}]$ を 含み, 調音がより複雑と思われる単語に関し, アクセ ント指令と $[\mathrm{m}]$ の閉鎖時点との時間関係を調べた。

\section{II。実験 1：語頭に母音連続を含む発話の分析}

\section{1. 被験者}

対象は脳内出血を原因疾患とする発語失行症患者 で，発症後 6 年を経過した 27 歳の右利き女性である。 神経学的所見として, 右上下肢・右顔面の不全麻㽽が みられた. X 線 CT 所見によれば，主に左第 2 前頭回・ 第 3 前頭回・中心前回の皮質および皮質下に比較的限 局した低吸収域が認められた。失語症検查の成績は発 話面を除いてほほ満点であった。発話の特徵としては, 
一貫性のない調音の誤り（軽度〜中度）に加えて，発 話速度の低下と不規則な変動, およびポーズの挿入等 の韻律異常がみとめられた。以上の所見から対象はほ ぼ純粋な発語失行症と診断された。

対照群は 3 名の健常者とし心、いずれも右利きの女 性で, 2 名は 28 歳, 1 名は 30 歳であった。

被験者は発語失行症患者を含め，すべて東京方言の 話し手であった。

\section{2. 発話試料}

表 1 に発話試料を示す。発䚾試料は [ai] で始まり, 平板型・尾高型のアクセント ${ }^{19}$ ) 持つ(つまり 2 拍目で 基本周波数が上昇する) $3 \sim 5$ 拍の有意味単語 16 語で ある.これらの単語を毎秒 5 拍と 3.3 拍の発話速度で 1 回ずつ発話させた。発話速度を一定に保つため, あ らかじめ録音しておいた発話を聞かせ, 同じ発話速度 で発話するように指示した。なお，分析の対象とした 発語失行症患者の発話試料に流, 明らかな言い誤りや 歪は認められなかった。

\section{3. 分析方法}

1) アクセント指令の始点の推定

音声はテープレコーダに録音し, 標本化周波数 10 $\mathrm{kHz}$, 精度 12 bit で A/D 変换しコンピュータに取り 込んだ。

基本周波数はピーク検出法により抽出した。すなわ ち, 音声波の有声区間で声門の開大に対応する最初の ピークを, 各周期毎に検出し, 基本周波数を計算し た ${ }^{18)}$.

アクセント指令の始点の推定は, 藤崎らの仮定 ${ }^{18)} に$

表 1 実験 1 の発話試料

\begin{tabular}{|c|c|}
\hline 間 & [aida] \\
\hline 相手 & [aite] \\
\hline 合間 & [aima] \\
\hline 藍色 & [aiifo] \\
\hline 相生 & [aioi] \\
\hline 合鍵 & [aikani] \\
\hline 愛犬 & [aikeN] \\
\hline 愛妻 & [aisai] \\
\hline 哀愁 & [aijur:] \\
\hline 愛情 & [aid3o:] \\
\hline 愛着 & [ait\}akur] \\
\hline 曖昧 & [aimai] \\
\hline 愛用 & [aijo:] \\
\hline アイロン & [aifon] \\
\hline 間柄 & [aidanafa] \\
\hline 相手役 & [aitejaku] \\
\hline
\end{tabular}

基づき行った。すなわち，抽出された基本周波数の 数表示 $\ln \mathrm{F}_{0}(\mathrm{t})$ を式(1)により近似した。

$$
\begin{aligned}
& \ln F_{0}(t)=\operatorname{In} F_{m I n}+A_{p} G_{p}\left(t-T_{p}\right)+A_{a} G_{a}\left(t-T_{a}\right) \\
& \text { シだし, }
\end{aligned}
$$

$\mathrm{F}_{\mathrm{m} \ln }$ : 声带振動が可能な最低基本周波数

$A_{p}$ : フレーズ指令の大きさ

$\mathrm{A}_{\mathrm{a}}$ : アクセント指令の大きさ

$\mathrm{T}_{\mathrm{p}}$ : フレーズ指令の始点

$\mathrm{T}_{\mathrm{a}}$ : アクセント指令の始点

また， $\mathrm{G}_{\mathrm{p}}(\mathrm{t}) ， \mathrm{G}_{\mathrm{a}}(\mathrm{t})$ 㹥それぞれ，フレーズ成分を形 成するインパルス応答，アクセント成分を形成するス テップ応答であり次式で与えられる。

$$
\begin{aligned}
& G_{p}(t) \begin{cases}=\alpha^{2} t \cdot \exp (-\alpha t) & t \geqq 0 \ldots \cdots(2 ; \\
=0 & t<0\end{cases} \\
& \mathrm{G}_{\mathrm{a}}(\mathrm{t}) \begin{cases}=\operatorname{Min}[1-(1+\beta \mathrm{t}) \cdot \exp (-\beta \mathrm{t}), \theta] & \mathrm{t} \geqq 0 \\
=0 & \mathrm{t}<0\end{cases} \\
& \text { ここで, }
\end{aligned}
$$

のステップ応答の固有角周波数

心お，式(3)は $\mathrm{G}_{\mathrm{a}}(\mathrm{t})$ が $\mathrm{t}$ の增加に伴って臨界制動二 次系のステップ応答上して増加するが，あらかじめ設 定した上限値 $\theta(=0.9)$ に達した後は，一定值 $\theta$ とな ることを示している.

アクセント指令の始点 $\mathrm{T}_{\mathrm{a}}$ の推定にあたっては, 基本 周波数の実測值に対し自乗誤差を最小とする式(1)～(3) のハララメー夕, $\mathrm{F}_{\mathrm{m} \mid \mathrm{n}}, \mathrm{A}_{\mathrm{p}}, \mathrm{A}_{\mathrm{a}}, \mathrm{T}_{\mathrm{p}}, \mathrm{T}_{\mathrm{a}}, \alpha, \beta$ を, 「合 成による分析法」を用いて求めた。このときの $\mathrm{T}_{\mathrm{a}}$ をア クレント指令の始点とした。

2 ) 調音指令の始点の推定

フォルマント周波数の抽出にあたっては，まず，ピ ッチ同期の FFTにより音声スペクトル包絡を求め た。次に，「合成による分析法」により第 1 第 4 フォ ルマント周波数を抽出した ${ }^{18.20)}$.さらに, 藤崎らの手 法 ${ }^{18.211}$ に従い, 調音指令の始点を推定した。

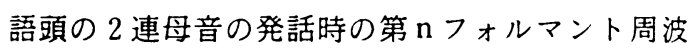
数の遷移 $F_{n}(t)$ は式(4)に示す臨界制動二次系のステッ ブ応答により近似できる。

$$
\begin{aligned}
& \quad F_{n}(t)=F_{n 1}+\left(F_{n 2}-F_{n 1}\right) G_{1}\left(t-T_{f}\right) \cdots \cdots(4) \\
& \text { たたし, }
\end{aligned}
$$

$\mathrm{F}_{\mathrm{n} 1}$ : 第 1 母音の第 $\mathrm{n}$ フォルマント周波数

$\mathrm{F}_{\mathrm{n} 2}$ : 第 2 母音の第 $\mathrm{n}$ フォルマント周波数

$T_{\mathrm{f}}$ : 第 2 母音の調音指令の始点 
Vol. 31 No. 2, 1990. 4

また, $G_{f}(t)$ はステップ応答であり次式で与えられ

๖.

$$
G_{f}(t)\left\{\begin{array}{lc}
=\operatorname{Min}[1-(1+\gamma t) \cdot \exp (-\gamma t), \theta] & t \geqq 0 \\
& \cdots \cdots(5) \\
=0 & t<0
\end{array}\right.
$$
ただし，

$\gamma \quad$ : フォルマント周波数の遷移区間に対する 臨界制動二次系のステップ応答の固有角 周波数.

なお，式(5)は式(3)と同様に上限值 $\theta(=0.9)$ を持つ ステップ応答である.

ところで, 後舌母音 $[\mathrm{a}]$ と前舌母音 [i] が連続する 場合, 第 2 ・第 3 フォルマントは順序が入れ替わるが, それぞれの共振モード間の結合により，現実のフォル 、ント周波数の遷移には交叉はみられない。藤崎らは 二の過程を，共振周波数の近い共振回路が電磁気的に 結合された場合，実際の共振周波数が相互に離れる方 向に変化する性質を用いてモデル化した ${ }^{22}$. 本研究で も，第 2 ・第 3 フォルマントの遷移 $\left(\mathrm{F}_{2}(\mathrm{t}), \mathrm{F}_{3}(\mathrm{t})\right)$ の 近似にこのモデルを採用した。

調音指令の始点の推定にあたっては，語頭から第 2 母音の定常部終了時点までの第 1 〜第 3 フォルマント 周波数の実測值に対し，自乗誤差を最小とする式(4), (5)のパラメー夕, $\mathrm{F}_{\mathrm{n} 1}, \mathrm{~F}_{\mathrm{n} 2}, \mathrm{~T}_{\mathrm{f}}, \gamma$ を,「合成による分 析法」を用いて求めた。このときの $\mathrm{T}_{\mathrm{f}}$ を調音指令の始 点とした。
3 ）推定結果の例

図1は発語失行症患者の発話におけるアクセント指 令と調音指令の始点の推定例である。中段の十印が抽 出された基本周波数, 破線は推定されたフレーズ成 分, 十印とほぼ重なっている点線はフレーズ成分とア クセント成分との和の近似曲線である。一方, 下段

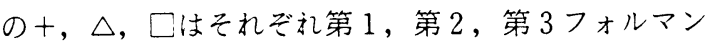
卜周波数, 実線のステップ関数が調音指令, 点線が調 音指令に対する応答である. 基本周波数, フォルマン 卜周波数のいずれの近似曲線も推定値とよく一致して いる。なお，推定されたアクセント指令の始点 $\mathrm{T}_{\mathrm{a}}$ と第 2 拍の [i] の調音指令の始点 $\mathrm{T}$ : 汢図中に点線で表示し た。

\section{4. 結 果}

図 2 と図 3 にそれぞ记健常者と発語失行症患者の結 果を示す。綐軸にアクセント指令の始点 $\mathrm{T}_{\mathrm{a}}$ を, 横軸に 第 2 拍目の [i] に対する調音指令の始点 $T_{\mathrm{f}}$ をとり, 測 定值の分布を示している。斜めの点線は $T_{a}$ と $T_{\mathrm{f}}$ が等 しい場合を表す。図中，○と山はそれぞれ毎秒 5 拍と 3.3 拍の発話速度における結果を示している.

図 2 の健常者においては, 毎秒 5 拍の発話速度の場 合，測定值は点線の上下に活济均等に分布している. すなわち，アクセント指令が調音指令に対して最大で $60 \mathrm{~ms}$ 先行する場合から $60 \mathrm{~ms}$ 遅延する場合まであっ た。一方, 毎秒 3.3 拍の発話速度では, 被験者により 幾分差が認められるが，点線より上方に分布すること

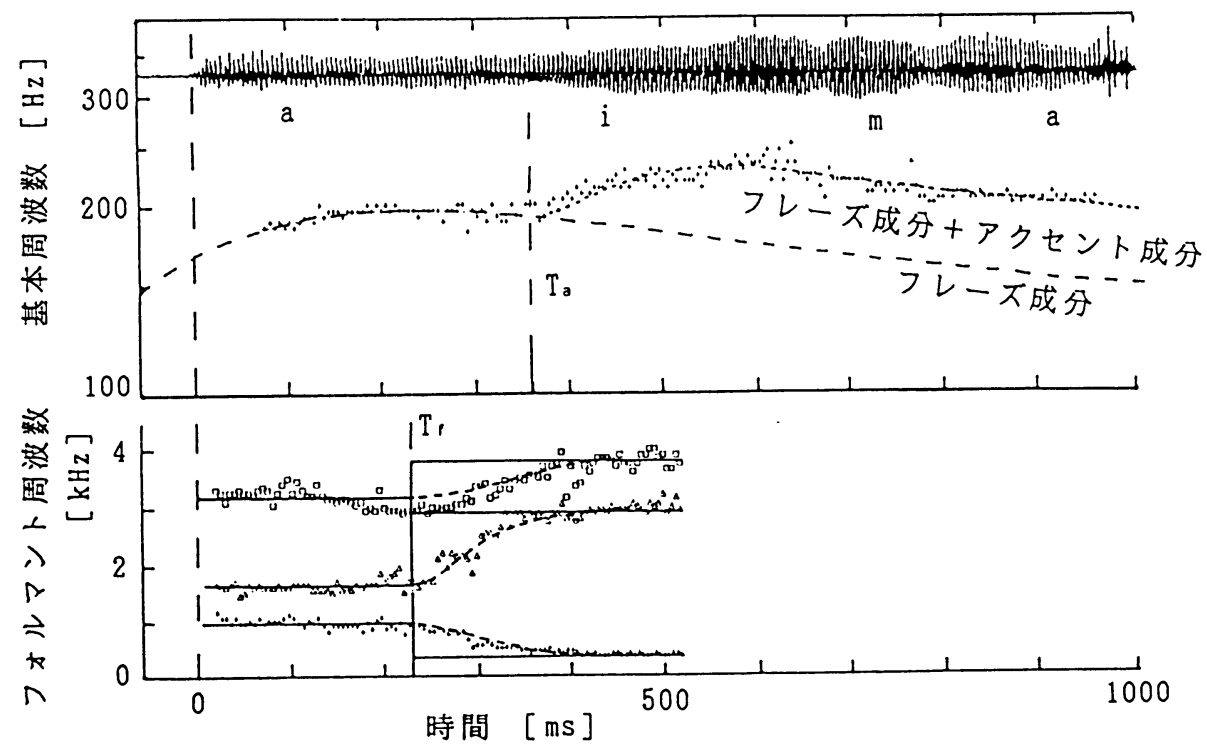

図 1 発語失行症患者の発話試料 [aima] (合間) を音響分析し, 藤 崎らの手法により推定したアクセント指令の始点 $\left(\mathrm{T}_{\mathrm{a}}\right)$ と第 2 母音 $[i]$ の調音指令の始点 $\left(T_{\mathrm{f}}\right)$ 


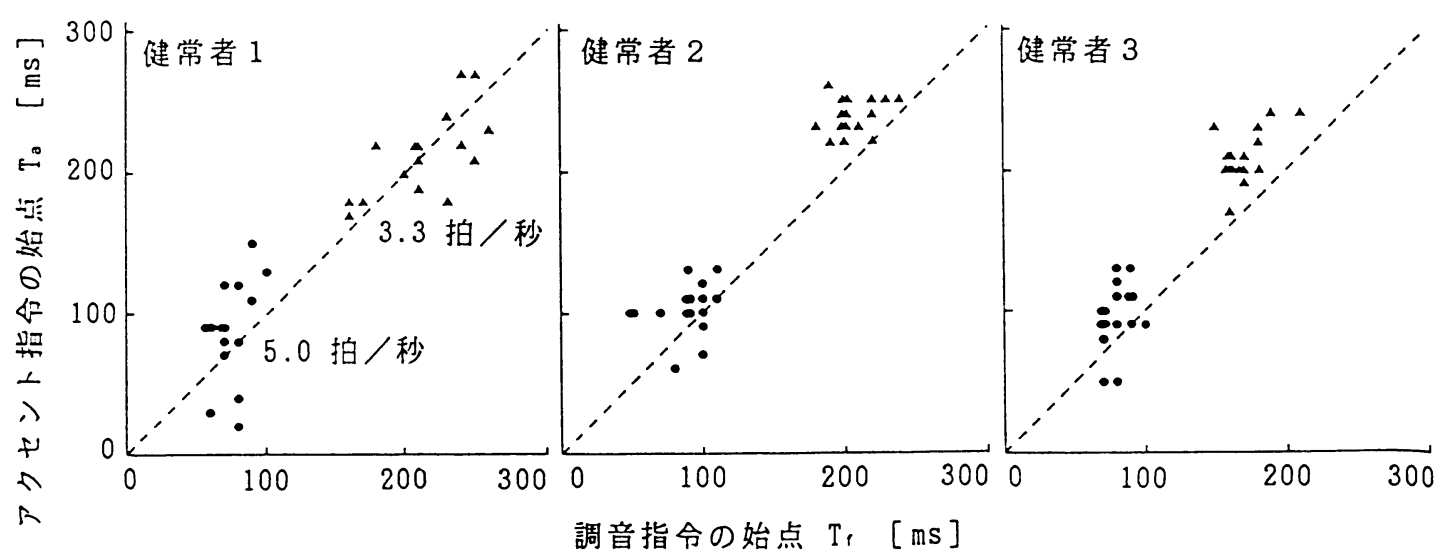

図2 健常者の発話におけるアクセント指令の始点 $\left(T_{\mathrm{a}}\right)$ と第 2 母 音 $[i]$ の調音指令の始点 $\left(T_{f}\right)$ との時間関係

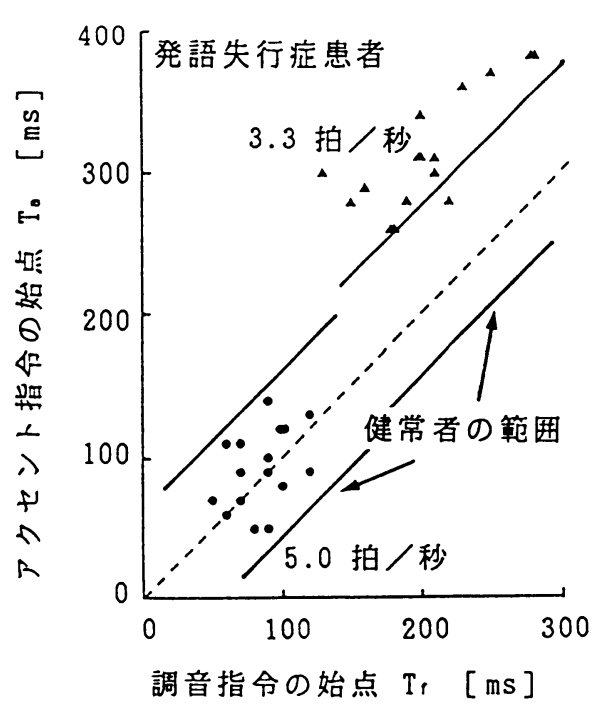

図3発語失行症患者の発話におけるアクセント 指令の始点 $\left(\mathrm{T}_{\mathrm{a}}\right)$ と第 2 母音 $[\mathrm{i}]$ の調音 指令の始点 $\left(T_{f}\right)$ との時間関係

が多く，調音指令がアクセント指令より先行する傾向 がみられた。また，推定値つ分布範囲は，アクセント 指令が調音指令に対して $50 \mathrm{~ms}$ 先行する場合から 80 $\mathrm{ms}$ 遅延する場合まであった。

図 3 は発語失行症患者の結果を示す。毎秒 5 拍の発 話速度では, 健常者と同様に測定值は点線の上下にほ ぼ均等に分布している.アクセント指令は最大で 40 $\mathrm{ms}$ 先行する場合から $50 \mathrm{~ms}$ 遅延する場合まである が, これは健常者の分布域内にある.これに対し, 毎 秒 3.3 拍では, 測定値がすべて点線の上方に分布して おり, 全発話でアクセント指令が調音指令より遅れて
発せられたことを示している．遅れの程度は健常者の 場合より著しく大きく, 最大 $160 \mathrm{~ms}$ 遅れていた。さら に, 16 発話中 13 の発話で健常者における最大の遅延 時間 $80 \mathrm{~ms}$ を越える遅延がみられた。

\section{III. 実験 2 ：第 2 拍に [m] を含む発話の分析}

\section{1. 被験者}

実験 1 と同じ発語失行症患者を被験者とした。対照 群は実験 1 で対象とした健常者 3 名の内の 2 名であ 3.

\section{2. 発話試料}

表 2 に発話試料示す。発話試料は $[\mathrm{amV}](\mathrm{V}=\mathrm{a}$, $\mathrm{e}, \mathrm{i})$ で始まる, 平板型・尾高型のアクセントを持つ 3 〜 拍の有意味単語 12 語である.これらの単語を, 每 秒 5 拍および 3.3 拍の発話速度で発話させた. 実験 1 と同様に，あらかじめ録音しておいた発話を聞かせ， 同じ発話速度で発話するように指示した。しかしなが ら, 発語失行症患者では毎秒 5 拍の発話を行わせた之 ころ，実際の発話速度は毎秒約 3 拍であった。そこで 患者には, 毎秒 3.3 拍の発話は行わせなかった。 なお, 分析の対象とした患者の発話試料には, 明らかな言い 誤りや歪は認められなかった。

\section{3. 分析方法}

1) アクセント指令の始点の推定

実験 1 と同様の方法を用いた。

2 ) $[\mathrm{m}]$ の唇閉鎖の始点の推定

健常者の発話では，第 2 拍の $[\mathrm{m}]$ の唇の閉鎖に対応 して急激に音声振幅が減少する時点を $[\mathrm{m}]$ の唇閉鎖開 始時点 $T_{\mathrm{m}}$ とした。しかし, 発語失行症患者の発話にお いては，振幅が減少しないことがあった。その場合に は, 同時に行った唇の運動観測 ${ }^{23}$ に基づき,下唇の上昇 
Vol. 31 No. $2,1990.4$

呢認し，また音声波形を観測して $[\mathrm{m}]$ の唇閉鎖に伴 j形の急激な変化を検出し, $[\mathrm{m}]$ の唇閉鎖開始時点 T正決定した。

3）推定結果の例

图4 は発語失行症患者の発話におけるアクセント指 命の推定例である。図中にアクセント指令の始点 $\mathrm{T}_{\mathrm{a}}$ 上，第 2 拍の $[\mathrm{m}]$ の唇閉鎖の始点 $\mathrm{T}_{\mathrm{m}}$ とを点線で示し $\therefore$. 以下では両者の時間関係について述べる。

\section{4. 結果}

図5に健常者の結果を示す。縦軸にアクセント指令 つ始点 $\mathrm{T}_{\mathrm{a}}$ を，横軸に $[\mathrm{m}]$ の唇閉鎖の始点 $\mathrm{T}_{\mathrm{m}}$ をとり， 测定値の分布を示した．斜めの点線は $\mathrm{T}_{\mathrm{a}}$ と $\mathrm{T}_{\mathrm{m}}$ が等し い場合を表す。は毎秒 5 拍の発話速度での結果を表 し，ムは毎秒 3.3 拍の発話速度での結果を表す。

2 名の健常者においては, 毎秒 5 拍, 3.3 拍のいずれ 刀発話速度においても, 測定值はほほ点線の近傍に分 布した。すなわち, 毎秒 5 拍の発話ではアクセント指

表 2 実験 2 の発話試料

\begin{tabular}{|c|c|c|}
\hline \multirow[t]{7}{*}{ [ama .. ] : } & 雨乞い & [amagoi] \\
\hline & 甘酒 & [amadzake] \\
\hline & 雨雲 & [amanumo] \\
\hline & 甘ロ & [amakuttii] \\
\hline & 甘塩 & [amadzio] \\
\hline & 雨脚 & [amaaji] \\
\hline & あまえんぼう & [amaembo:] \\
\hline \multirow[t]{2}{*}{ [ame...]: } & 飴玉 & [amedama] \\
\hline & あめんぼう & [amembo:] \\
\hline \multirow[t]{3}{*}[\operatorname{ami}..]{$:$} & 阿弥陀 & [amida] \\
\hline & 網棚 & [amidana] \\
\hline & 網元 & [amimoto] \\
\hline
\end{tabular}

令は $[\mathrm{m}]$ の唇閉鎖に対して最大で $30 \mathrm{~ms}$ 先行する場合 から $10 \mathrm{~ms}$ 遅延する場合までであり, 毎秒 3.3 拍の発 話では, 同じく最大で $30 \mathrm{~ms}$ 先行する場合から, $20 \mathrm{~ms}$ 遅延する場合までであった。

図 6 に発語失行症患者の結果を示す。健常者の場合 と異なり，測定値は点線より上にある場合，すなうち アクセント指令が， [m]の唇閉鎖に対して遅延する場 合が多いことを示している。しかも，遅延の程度が著 しく, 36 発話中 19 の発話で健常者における最大の遅 延時間 $20 \mathrm{~ms}$ を越える遇延がみられ，遅れの最大値は $160 \mathrm{~ms}$ に達した。一方，アクセント指令が先行すると

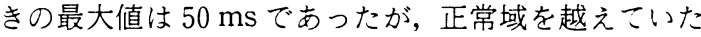
のはこの場合のみであった。

\section{IV. 考 察}

発語失行症患者の単語アクセント生成時の調音器官 と発声器官の協調運動を調べるために，ほほ純粋な発 語失行症患者 1 例と健常者を対象として, 平板型・尾 高型のアクセントをもつ単語を発話したときの，第 2 拍の調音指令とアクセント指令の時間関係を調べた。

まず，健常者の結果をまとめると，実験 1 では，[ai] で始まる単語の発話を調べ，普通の速度（毎秒 5 拍） で発話した場合，アクセント指令の始点と調音指令の 始点がほぼ同期していたのに対し，遅い発話速度（毎 秒 3.3 拍）では，アクセント指令が遅れる傾向のある ことを明らかにした。

同様の結果は，すでに藤崎らにより示されている。 彼らは母音連続からなる2 拍単語 [ai] の発話におい て，アクセント指令が第 2 拍目の母音 [i] への調音指 令より数十 ms 遅れること, 遅れの程度は発話速度の 低下に伴い大きくなる傾向があること，等を見出し

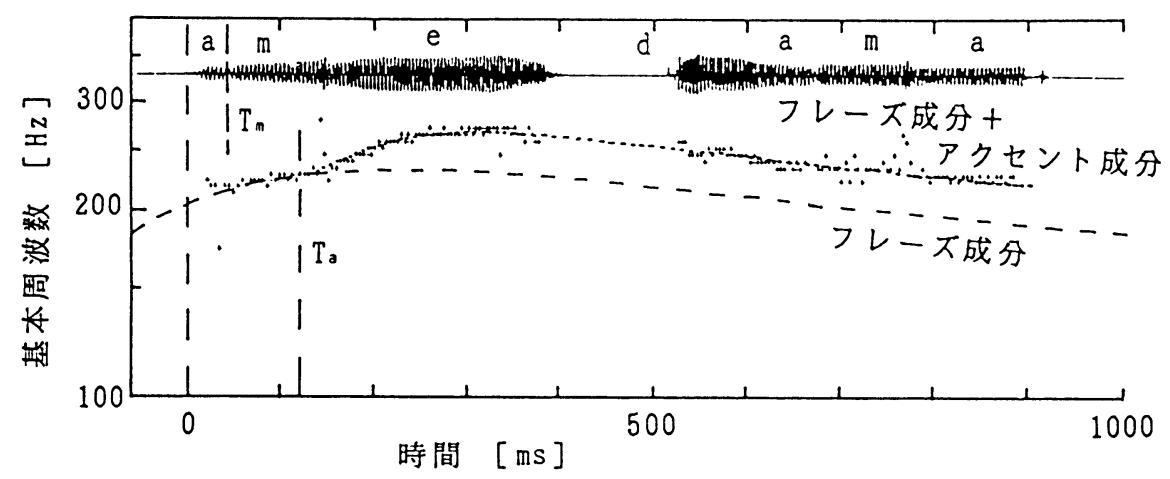

図4 発語失行症患者の発話試料 [amedama]（飴玉）を音響分析 し, 藤崎らの手法により推定したアクセント指令の始点 $\left(\mathrm{T}_{\mathrm{a}}\right)$ と第 2 拍目の $[\mathrm{m}]$ の唇閉鎖の始点 $\left(\mathrm{T}_{\mathrm{m}}\right)$ 


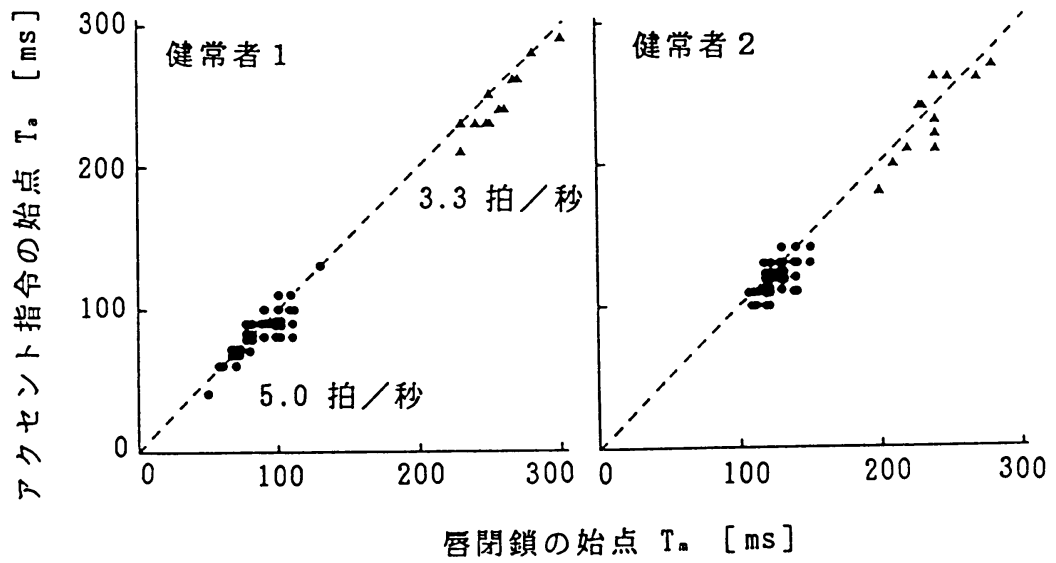

図 5 健常者の発話におけるアクセント指令の始点 $\left(T_{\mathrm{a}}\right)$ と第 2 拍 目の $[\mathrm{m}]$ の唇閉鎖の始点 $\left(\mathrm{T}_{\mathrm{m}}\right)$ との時間関係

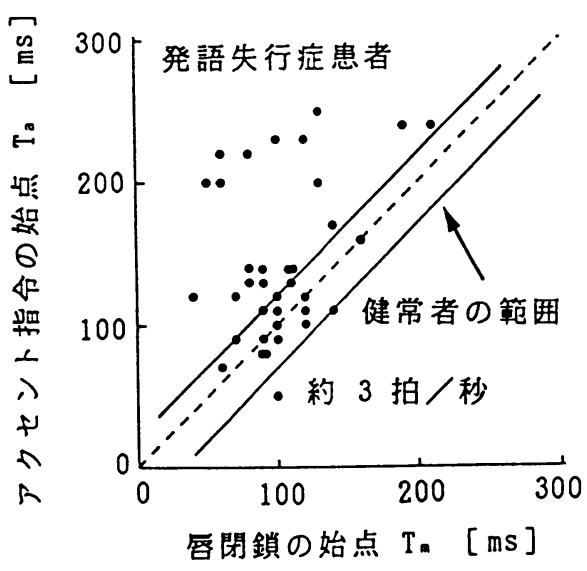

図6発語失行症患者の発話におけるアクセント 指令の始点 $\left(\mathrm{T}_{\mathrm{a}}\right)$ と第 2 拍目の $[\mathrm{m}]$ の唇 閉鎖の始点 $\left(T_{m}\right)$ Łの時間関係

た ${ }^{18.24)}$.このようなアクセント指令の遅れを生じる機 構としては以下の仮説を考えることができる，すなわ ち, 調音の変化を聴覚的に検知し, しかる後にアクセ ント指令が発せられるため,アクセント指令が遅れる, との仮説である。しかし，中途失聴者では聴力損失が 高度であってもアクセント異常は生じない.また，本 実験の結果は, 普通の発話速度において, アクセント 指令が調音指令と同時，あるいはそれより先行する場 合もみられた。したがって, 調音指令とアクセント指 令の時間関係の決定に，必ずしも聴覚は関与していな いものと考えられる。むしろ, 調音器官と発声器官の 運動指令の時間関係は予めプログラム化されているも
のと推察される.

一方，実験 2 では，[amV]で始まる単語を用い，? クセント指令と調音指令の時間関係を調べた。第 2 扰 の調音の参照点としては，便宜的に $[\mathrm{m}]$ の唇閉鎖時点 をとった。その結果，アクセント指令は発話速度にd らず $[\mathrm{m}]$ の唇閉鎖とほほ同期することが明らかとなっ た。母音連続を含む試料における第 2 拍の始点は， フ オルマント変化の始点と考えられるのに対し, $[\mathrm{m}] \sigma_{j}$ 唇閉鎖時点は, 必ずしも第 2 拍の始点とは一致しない， したがって，[m]に関し得られた結果の解积にあた。 ては, さらに検討を要するが, $[\mathrm{m}]$ を含む試料におい てもアクセント指令が調音器官の運動と一定の時間関 俰を保って発せられることは，母音連続に関して得ら れた結果と, 同様の傾向を示すものと思われる.

次に, 発語失行症患者の結果をまとめると, [ai] 語頭に持つ単語を, 普通の速度（毎秒 5 拍）で発話し た場合，健常者と同様にアクセント指令と調音指令注 ほほ同期していた.しかし,遅い発話速度(毎秒 3.3 拍) では, アクセント指令が健常者に比べると, 䫓著に荤 れる傾向が見られた。 $[\mathrm{amV}]$ を語頭に持つ単語におい ても, 遅い発話速度（毎秒約 3 拍）ではアクセント指 令か $[\mathrm{m}]$ の唇閉鎖に対して顕著に遅れる場合が多かっ た。このように, 本実験で対象とした発語失行症患者 では発話速度が遅いときには, 発声器官と調音器官の 間の協調が崩れ, 韻律異常が出現する.

はじめに述べたように, Darley らは多くの先行研究 の結果に基づいて, 発語失行症にみられる発話の異常 はまず調音に現れるとし, ポーズの扱入, 発話速度の 低下, 強勢の平坦化等の韻律異常は, 調音の難しさの 
Vol. 31 No. 2. 1990. 4

※ふに生ずる「補償現象」であるとの見解を示しだ”。 これに対して, 発語失行症では正しく調音された発話 においても，発話速度の低下，強勢や抑揚の異常が生 じることなどから，発語失行症患者に見られる韻律異 营が「補償現象」とはみなし難いとする主張もある $3^{i 1.25)}$, データは示されていない.

以下では，この点に関して検討したい，まず，伊藤 らは, ファイバースコープを用いてロ蓋帆の運動を観 測し，鼻子音 $[\mathrm{n}]$ の区間での口蓋帆の下降運動は見ら れるものの, 下降のタイミングや下降速度は発話毎に 大きく変動することを見出した ${ }^{12)}$.さらに伊藤らは, X 線マイクロビームを用いて, 唇・舌・口蓋帆の調音運 動を観測し，鼻子音 [n] の区間で口蓋帆の動きが他の 調音器官の動きと協調していない場合のあることを明 らかにした ${ }^{13)}$.すなわち, 発語失行症患者の発話では, 複数の調音器官の動きに協調異常が存在し, 調音の異 常が生じることが示された。一方，杉下らは，人工口 盖を用いて発語失行症患者の発話を観測し,「舌と硬口 蓋の構え」は形成されているにもかかわらず, 発声器 官による声立てが遅れるために語頭の子音が省略され る場合があることを明らかにしだ).すなわち，子音の 省略が調音器官と発声器官の協調異常のために生じる ことが示された。ささらに本実験の結果は, 発声器官に よる基本周波数制御が調音運動と協調していない場合 のあることを示している.

これらの実験結果を総合すると, 今回対象とした発 語失行症患者に見られたアクセント指令の遅れは, 伊 藤らの観測した子音の歪や置換，さらに杉下らの観測 した子音の省略とほぼ同一，ないし類似の障害機構に より生じているものと推察される，換言すれば，発語 失行症の韻律異常は, 調音の困難さに伴う補償現象で はないと思われる。

このように, 発語失行症に見られる韻律異常（アク セント指令の遅れ）は, 調音の異常とほぼ同一の障害 機構により生じるものと思われるが, 両者の異常の程 度は著しく異なるようである.今回対象とした患者に おける調音異常は, 歪のみならず音素の置換がしばし ば見られるが, 韻律に関しては, アクセント指令の遅 れが第 2 拍を越えて第 3 拍目に及ぶことはなく, 単語 アクセントが変わることはなかった，単語アクセント が保たれていることは Sasanuma ${ }^{5)}$ も聴覚印象に基づ き示している．英語を母国語とする患者についても， 類似の現象が報告されている. Kent and Rosenbek ${ }^{11)}$ は, 音素の置換などの調音の異常を示している患者の 発話を試料とし，強勢やイントネーションに関してサ ウンドスペクトログラフおよびVisi-Pitch (Kay
Elemetrics 社製）を用いて，短文内の各音節の中心部 の音の強度と基本周波数を測定した。その結果, (1)強 度の変動幅は健常者より減少するものの, 最大の強度 を示す音節（つまり強勢）の位置は健常者と同じごあ ること，(2)基本周波数については被験者間のばらつき があるが，文末で基本周波数が低下する傾向は，健常 者と同様に保たれていること,などが明らかにされた。 このように，アクセント，強勢などの韻律の異常は， 調音の場合とは異なり, 音韻の変化を生じるほど著し いものではない。

では，今回対象とした患者の発話に見出されたアク セント指令の遅れは，発話の聴覚印象に対してどのよ うな影響を与えるのであろうか.これについては現在 のところ参照すべきデータがなく，推測の域を出ない が,おそらく今回対象とした患者の発話から受ける「立 ち上がりが悪く」「歯切れの悪い」「引きずる」ような 聴覚印象は，アクセント指令の遅れが一因となり生じ ているものと考えられた。

本研究は, 一例の発語失行症患者の発話を音響分析 し, 調音器官と発声器官の協調運動について検討した ものであるが，同様の現象が他の発語失行症患者にも 見られるものか否か, 今後症例を増やして検討する必 要があろう。

データ収集にご協力いただいた虎の門病院分院の藤林道理子 先生, 土田昌一先生に感謝する.また, 調音器官の運動観椡装置 の開発にご協力いただいた東京都老人医療センターの渡辺邰馬 先生, 東京歯科大学の中沢勝宏先生に感謝する. 本研究の一部は 文部省科学研究費, 䍒励研究(A) 63772007 により行われた。

\section{文献}

1) Darley, F. L., Aronson, A. E., and Brown, J. R. : Motor speech disorders, Saunders, 1975.

2) Shankweiler, D. and Harris, K. S. : An experimental approach to the problems of articulation in aphasia, Cortex, 2, 277-292, 1966.

3) Johns, D. F. and Darley, F. L. : Phonemic variability in apraxia of speech, Journal of Speech and Hearing Research, 13, 556-583, 1970.

4) Deal, J. L. and Darley, F. L. : The influence of linguistic and situational variables on phonemic accuracy in apraxia of speech, Journal of Speech and Hearing Research, 15, 639-653, 1972.

5) Sasanuma, S. : Speech characteristics of a patient with apraxia of speech ; a preliminary case report, Annual Bulletin of Research Insti- 
tute of Logopedics and Phoniatrics, University of Tokyo, 5, 85-89, 1971.

6）今泉 敏, 桐谷 滋, 寺輪あき子, 森木紀恵, 白 井克彦：話者および発話速度によるフォルマント 軌跡の変動特性, 電子情報通信学会音声研究会資 料, SP 87-131，1988.

7) 紺野加奈江, 杉下守弘, 廣瀬 肇: 純粋型発語失 行症 5 例における誤りタイプの分析, 音声言語医 学, 29, 107, 1988.

8）杉下守弘, 紺野加奈江, 加部澄江, 柚木和太, 富 樫 修, 河村 満: 純粋語啞の二症例の音声学的 分析, 失語症研究, $5,836-847,1985$.

9) Trost, J. E. and Canter, G. J. : Apraxia of speech in patients with Broca's aphasia: a study of phoneme production accuracy and error patterns, Brain and Language, 1, 63-79, 1974.

10) LaPointe, L. L. and Johns, D. F. : Some phonemic characteristics in apraxia of speech, Journal of Communication Disorders, 8, 259269, 1975.

11) Kent, R. D. and Rosenbek J. C. : Acoustic patterns of apraxia of speech, Journal of Speech and Hearing Research, 26, 231-249, 1983.

12) Itoh, M., Sasanuma, S. and Ushijima, T. : Velar movements during speech in a patient with apraxia of speech, Brain and Language, 7, 227239, 1979.

13) Itoh, M., Sasanuma, S., Hirose, H., Yoshioka, H. and Ushijima, T. : Abnormal articulatory dynamics in a patient with apraxia of speech : $\mathrm{X}$-ray microbeam observation, Brain and Language, 11, 66-75, 1980.

14）紺野加奈江, 祄下守弘, 廣瀬 肇：発語失行にお ける構音運動, 電子情報通信学会音声研究会資料, SP 87-82, 1987.

15) Kent, R. D. and Rosenbek, J. C. : Prosodic disturbance and neurologic lesion, Brain and Language, 15, 259-291, 1982.

16）紺野加奈江，杉下守弘，廣瀬 肇：Apraxia of speechにおける持続時間の流暢性評価への影䎪, 電子情報通信学会音声研究会資料, SP 86-98, 1987.

17）日暮嘉子, 正木信夫, 辰巳 格, 笹沼澄子：発挔 失行症における韻律異常一持続時間の異常一, 首 声言語医学, 29, 307-315, 1988.

18) Fujisaki, H. : Functional models of articulator; and phonatory dynamics. Temporal organiza. tion of articulatory and phonatory controls in realization of Japanese word accent, Dynamic Aspects of Speech Production, University of Tokyo Press, 348-368, 1977.

19）日本放送協会編集：日本語発音アクセント辞典, 日本放送出版協会, 1989 .

20) Bell, C. G., Fujisaki, H., Heinz, J. M., Stevens K. N. and House, A. S. : Reduction of speech spectra by analysis-by-synthesis techniques, Journal of the Acoustical Society of America, 33, 1725-1736, 1961.

21) Fujisaki, H., Yoshida. M.. Sato, Y. and Tanabe. Y. : Automatic recognition of connected vowels using a functional model of the coarticulatory process, 日本音響学会誌, 29, 636-638, 1973.

22）藤崎博也, 吉田 賢, 佐藤吉幸：調音結合モデル に基づく母音・半母音の認識, 昭和 49 年度電子通 信学会全国大会講演論文集，1437，1974。

23）正木信夫, 辰巳 格, 笹沼澄子: 発語失行症患者 の発話における調音とピッチの時間関倸, 電子情 報通信学会音声研究会資料, SP 87-83，1987.

24）藤崎博也, 森川博由, 廣瀬 肇, 杉藤美代子：単 語アクセントの生成における調音と音調の時間関 係について，日本音響学会音声研究会資料，S 7632, 1976.

25）伊藤元信：発語失行症,耳鼻咽喉科・頭頸部外科 MOOK, 4, 152-168, 1987.

別刷請求先：干 173 東京都板橋区栄町 35-2

東京都老人総合研究所, 言語恥覚研究室 正木 信夫 